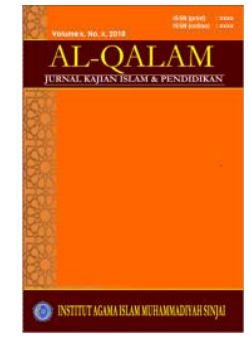

AL-QALAM

Jurnal Kajian Islam \& Pendidikan

Volume 8, No. 2, 2016

ISSN (print) : 1858-4152

ISSN (online) : xxxx-xxxx

Homepage : http://journal.iaimsinjai.ac.id/index.php/al-qalam

\title{
TEORI BELAJAR BEHAVIORISTIK
}

\author{
Oleh : Safaruddin ${ }^{*}$
}

$* * *$

\begin{abstract}
Abstrak
Teori behavioristik adalah teori beraliran behaviorisme yang merupakan salah satu aliran psikologi dimana menurut teori ini belajar adalah perubahan tingkah laku sebagai akibat dari adanya interaksi antara stimulus dan respon. Menurut teori ini yang terpenting adalah masukan atau inputyang berupa stimulus dan keluaran atau output yang berupa respons. Teori ini mengutamakan pengukuran, sebab pengukuran merupakan suatu hal yang penting untuk melihat terjadi tidaknya perubahan tingkah laku tersebut. Adapun tokoh-tokoh aliran behaviorisme ini antara lain: Ivan Petrovich Pavlov, Thorndike, Waston, Clark Hull, Edwin Guthrie, dan Skiner. Behaviourisme disebut Islami karena ia mengajarkan besarnya pengaruh lingkungan terhadap manusia sebagaimana ungkapan sebuah hadits yang artinya: "Manusia dilahirkan dalam keadaan suci, maka kedua orang tuanyalah yang menjadikannya Yahudi, Nasroni atau Majusi." H.R.Bukhari)
\end{abstract}

Kata Kunci : Psikologi, Belajar, Behaviorisme

\section{PENDAHULUAN}

$\mathrm{M}$

engajar bukan semata-mata mentransfer ilmu yang dimilki oleh pendidik kepada peserta didiknya, pendidik dan peserta didik bukanlah benda mekanik atau robot akan tetapi pendidik maupun peserta didik dalam dunia pendidikan adalah manusia yang tentunya memilki keragaman, karakteristik dan ciri khas, serta kelebihan dan kekurangannya masing-masing.

Belajar tentunya memiliki berbagai macam taori yang telah dicetuskan oleh para pakar yang punya keahlian di berbagai bidang bidanh keilmuan punya sumbagsih yang penting dalam merumuskan teori belajar. Pemikiran-pemikiran mereke tentang manusia dan lingkungannya telah digunakan oleh para praktisi pendidikan dan pembelajaran untuk merumuskan teori belajar dan mempraktikkannya dalam kenyataan

Teori belajar telah banyak muncul mulai dari yang paling awal yakni teori behaviorisme hingga teroi belajar humanisme, seiring dengan berjalannya waktu mengikuti hukum humanisme kehidupan teori belajar tampaknya akan terus bermunculan dan bertambah Teori yang sudah ada terkadang dikritik dengan segala kekurangannya kemudian di sempurnakan.

\section{PEMBAHASAN}

\section{A. Pengertian Teori Belajar Behaviorisme}

*Dosen Tetap Pada Institut Agama Islam (IAI) Muhammadiyah Sinjai 


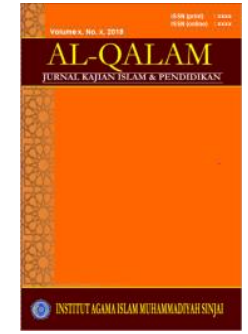

AL-QALAM

Jurnal Kajian Islam \& Pendidikan

Volume 8, No. 2, 2016

ISSN (print) : 1858-4152

ISSN (online) : xxxx-xxxx

Homepage : http://journal.iaimsinjai.ac.id/index.php/al-qalam

Psikologi merupakan ilmu pengetahuan yang belum lama lahir pada permulaan abad ke du puluh, dua aliran yang pada saat itu muncul yakni srtukturalisme dan fungsionalisme. Struktulalisme menggunakan metode instrospeksi (contoh tulisan Darwin tentang adaptasi dan evolusi) Fungsinalisme memiliki fokus studi yang terlalu luas. Maka, ditengah situasi ini teori behaviorisme muncul menjadi disiplin ilmu psikologi yang terkemuka ${ }^{1}$

Teori behavioristik adalah teori beraliran behaviorisme yang merupakan salah satu aliran psikologi. Teori belajar behavioristik ini dikenal dengan sebuah teori yang dicetuskan oleh $\underline{\text { Gage dan Berliner tentang perubahan tingkah laku sebagai hasil daripengalaman }}{ }^{2}$

Menurut teori behaviorisme, belajar adalah perubahan tingkah laku sebagai akibat dari adanya interaksi antara stimulus dan respon. Dengan kata lain, belajar merupakan bentuk perubahan yang dialami siswa dalam hal kemampuannya untuk bertingkah laku dengan cara yang baru sebagai hasil interaksi antara stimulus dan respon. Seseorang dianggap telah belajar sesuatu jika ia dapat menunjukkan perubahan tingkah lakunya ${ }^{3}$

Menurut teori ini yang terpenting adalah masukan atau input yang berupa stimulus dan keluaran atau output yang berupa respons. ${ }^{4}$ Stimulus adalah apa saja yang diberikan guru kepada siswa misalnya daftar perkalian, alat peraga, pedoman kerja atau cara-cara tertentu, untuk membantu belajar siswa, sedangkan respons adalah reaksi atau tanggapan siswa terhadap stimulus yang diberikan oleh guru tersebut. Dalam teori ini tingkah laku dalam belajar akan berubah apabila ada stimulus dan respons. Stimulus dapat berupa perlakuan yang diberikan kepada siswa, sedangkan respons berupa tingkah laku yang terjadi pada siswa. ${ }^{5}$

Menurut teori behaviorisme, apa yang terjadi diantara stimulus dan respons dianggap tidak penting diperhatikan karena tidak dapat diamati dan dan tidak dapat diukur. Yang dapat diamati hanyalah stimulus dan respons. Oleh karena itu, apa saja yang diberikan guru (stimulus), dan apa saja yang dihasilkan siswa (respons), semuanya harus dapat diamati dan diukur. Teori ini mengutamakan pengukuran, sebab pengukuran merupakan suatu hal yang penting untuk melihat terjadi tidaknya perubahan tingkah laku tersebut.

Faktor lain yang juga dianggap penting oleh aliran behavior adalah faktor pengutan (reinforcement). Penguatan adalah apa saja yang dapat memperkuat timbulnya respon bila pengutan ditambahkan maka respon semakin kuat. Begitu juga bila pengutan dikurangi responpun akan tetap dikuatkan. Misalnya, ketika peserta didik diberi tugas oleh guru, ketika tugasnya ditambahkan maka ia akan semakin giat belajarnya. Maka penambahan tugas tersebut merupakan penguat positif (positive reinforcement) dalam brlajar. Bila tugas-tugas dikurangi dan pengurangan itu justru meningkatkan aktifitas belajarnya, maka pengurangan tugas merupakan penguatan negatif (negative reinforcement) dalam belajar.

\footnotetext{
${ }^{1}$ Dale H. Schunk, Learning Teories, (Yogyakarta : Pustaka Pelajar, 2012) h. 99

${ }^{2}$ Gage, N.L., \& Berliner, D. Educational Psychology. 1979, h. 13

${ }^{3}$ C.Asri Budiningsih, Belajar dan Pembelajaran (Jakarta: PT. Rineka Cipta, 2005),h.21

${ }^{4}$ Suyono dan Harianto, Belajar dan Pembelajaran, Cet ke 3 ( Bandung : Belajar dan Pembelajaran,

${ }^{5}$ M. Sukarjo dan Ukim Komarudin, Landasan Pendidikan (Jakarta: PT. Raja Grafindo Persada,
} 2012) h. 59 2012), h.34. 
Jadi penguatan merupakan suatu bentuk stimulus yang penting diberikan atau dikurangi untuk memungkinkan terjadinya respon. ${ }^{6}$

\section{B. Tokoh-tokoh dan Pemikirannya Terhadap Teori Belajar Behavioristik}

Adapun tokoh-tokoh aliran behaviorisme ini antara lain : Ivan Petrovich Pavlov, Thorndike, Waston, Clark Hull, Edwin Guthrie, dan Skiner.

1. Ivan Petrovich Pavlov

Conditioning (pengkondisian atau persyaratan klasik) adalah proses yang ditemukan Pavlov melalui percobaannya terhadap anjing, dimana perangsang asli dan netral dipasangkan dengan stimulus bersyarat secara berulang-ulang sehingga memunculkan reaksi yang diinginkan. ${ }^{7}$

Eksperimen yang dilakukan oleh yang dilakukan oleh Pavlov sangat berpengaruh terhadapa pandangan behaviorisme yakni gejala-gejala kejiwaan seseorang dapat dilihat dari prilakunya hal ini sesuai dengan pendapat Bakker bahwa yang paling sentral dalam hidup manusia bukan hanya pikiran, peranan maupun bicara, melainkan tingkah lakunya. Pikiran mengenai tugas atau rencana baru akan mendapatkan arti yang benar jika ia berbuat sesuatu.Bertitik tolak dari asumsinya bahwa dengan menggunakan rangsangan-rangsangan tertentu, perilaku manusia dapat berubah sesuai dengan apa yang di inginkan. Kemudian Pavlov mengadakan eksperimen dengan menggunakan binatang (anjing) karena ia menganggap binatang memiliki kesamaan dengan manusia. Namun demikian, dengan segala kelebihannya, secara hakiki manusia berbeda dengan binatang. ${ }^{8}$

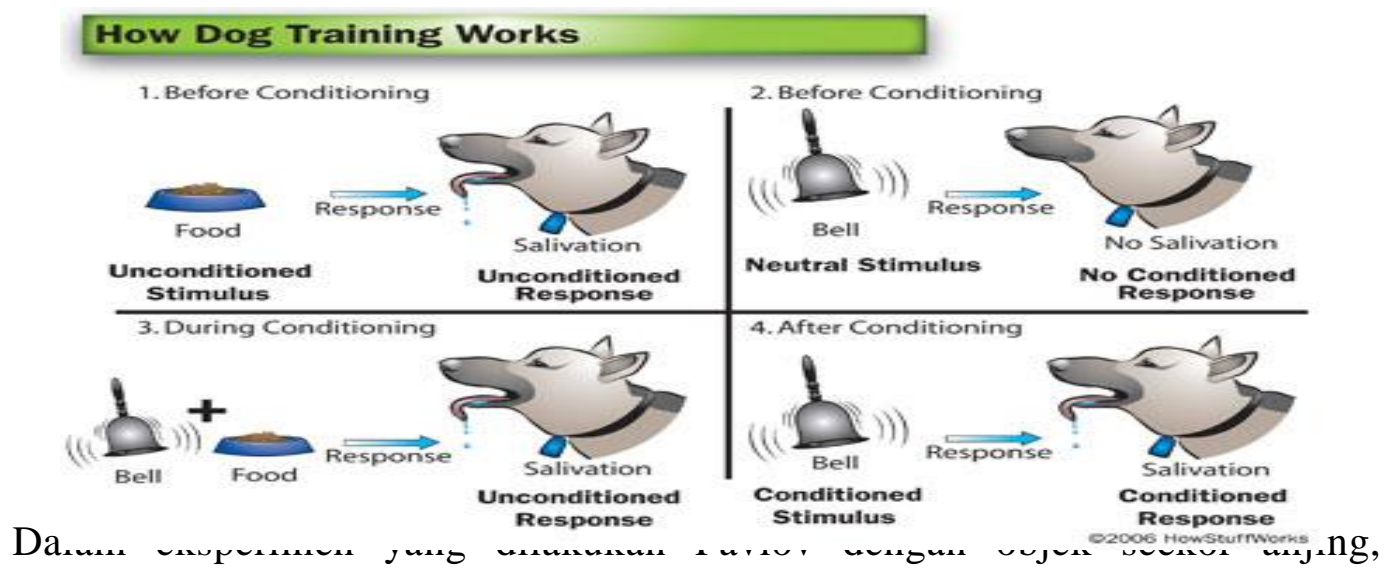

makanan dan bel sebagaimana pada gambar diatas maka ada beberapa unsur penting yang menyebabkan terjadinya proses pengkondisian

a. Unconditined Stimulus (US) yaitu rangsangan yang menghasilkan respon otomatis dan alamiah dari makhluk hidup (dalam hal ini makanan)

b. Unconditioned Response (UR) yaitu respon yang otomatis dan alamiah oleh US (dalam hal ini keluarnya air liur)

\footnotetext{
${ }^{6}$ Muhammad Tabroni dan Arif Mustafa, Belajar dan Pembelajaran (Jogjakarta : Ar-Ruzz Madia, 2011), h. 64

${ }^{7}$ Heri Rahyubi, Teori-teori belajar dan aplikasi pembelajaran motorik, (Bandung : Referens Publishing dan Nusamedia, 2013), h. 25

${ }^{8}$ Muhammad Tabroni dan Arif Mustafa, Belajar..., h. 83
} 


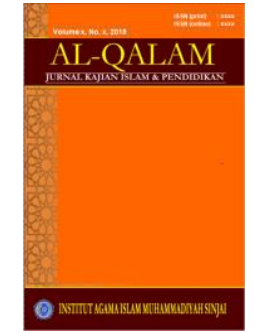

AL-QALAM

Jurnal Kajian Islam \& Pendidikan

Volume 8, No. 2, 2016

ISSN (print) : 1858-4152

ISSN (online) : xxxx-xxxx

Homepage : http://journal.iaimsinjai.ac.id/index.php/al-qalam

c. Conditioned Stimulus (CS) Ransangan netral yang dalam kondisi wajar tidak akan menghasilkan respon otomatis dan alamiah dari makhluk hidup (dalam hal ini bunyi)

d. Conditioned Response (CR) Respon terkondisi yang terjadi (yakni keluarnya air liur $)^{9}$

Berdasarkan hasil eksperimen itu Pavlov menyimpulkan bahwa hasil eksperimennya juga dapat diterapkan pada manusia untuk belajar. Impilkasi hasil eksperimen tersebut pada belajar manusia adalah: ${ }^{10}$

a. Belajar adalah membentuk asosiasi antara stimulus respon secara selektif.

b. Proses belajar akan berlangsung apabila diberi stimulus bersyarat.

c. Prinsip belajar pada dasarnya merupakan untaian stimulus-respon.

d. Menyangkal adanya kemampuan bawaan.

e. Adanya clasical conditioning.

Eksperimen Pavlov tersebut kemudian dikembangkan oleh pengikutnya yaitu BF. Skinner dan hasilnya dipublikasikan dengan judul Behavior Organism. Prinsipprinsip kondisioning klasik ini dapat diterapkan di dalam kelas adalah sebagai berikut:

a. Memberikan suasana yang menyenangkan ketika memberikan tugas-tugas belajar, misalnya menekankan kepada kerja sama, dan kompitisi antar kelompok individu. Membuat kegiatan membaca menjadi menyenangkan dengan menciptakan ruang baca yang nyaman dan enak serta menarik dan lain sebagainya.

b. Membantu siswa mengatasi secara bebas dan sukses situasi-situasi yang mencemaskan atau menekan, misalnya: mendorong siswa yang pemalu untuk mengajarkan siswa lain cara memahami materi pelajaran, membuat tahap jangka pendek untuk mencapai tujuan jangka panjang, misalnya dengan memberikan tes harian, mingguan, agar siswa dapat menyimpan apa yang dipelajari dengan baik.

c. Membantu siswa untuk mengenal perbedaan dan persamaan terhadap situasisituasi sehingga mereka dapat membedakan dan menggeneralisasikan secara tepat. Misalnya, meyakinkan siswa yang cemas ketika menghadapi ujian masuk sekolah yang lebih tinggi tingkatannya atau perguruan tiggi, bahwa tes tersebut sama dengan tes-tes akademik lainnya yang pernah mereka lakukan.

2. Edward LeeThorndike

Edward Lee Thorndike adalah seorang pendidik dan sekaligus psikolog berkebangsaan Amerika. Edward awalnya melakukan penelitian tentang prilaku binatang sebelum tertarik pada psikologi manusia ${ }^{11}$.

Thorndike menyatakan bahwa prilaku belajar manusia ditentukan oleh stimulus yang ada di lingkungan sehingga menimbulkan respon secara refleks. Stimulus yang terjadi setelah sebuah prilaku terjadi akan mempengaruhi prilaku

\footnotetext{
${ }^{9}$ Heri Rahyubi, Teori-teori belajar..., h. 27-28

${ }^{10}$ Zalyana, Psikologi Pembelajaran Bahasa Arab (Pekanbaru: Almujtahadah Press, 2010),h. 110-

${ }^{11}$ Mark K. Smith, dkk, Teori Pembelajaran dan Pengajaran,(Jogjakarta: Mirza Media Pustaka,2010),h.75
} 
Volume 8, No. 2, 2016

ISSN (print) : 1858-4152

ISSN (online) : xxxx-xxxx

Homepage : http://journal.iaimsinjai.ac.id/index.php/al-qalam

selanjutnya. Dari eksperimen ini Thorndike telah mengembangkan hukum Law Effect. Ini berarti jika sebuah tindakan diikuti oleh sebuah perubahan yang memuskan dalam lingkungan, maka kemungkinan tindakan itu akan diulang kembali akan semakin meningkat. Sebaliknya jika sebuah tindakan diikuti oleh perubahan yang tidak memuaskan, maka tindakan itu menurun atau tidak dilakukan sama sekali. Dengan kata lain, konsekuen-konsekuen dari prilaku sesorang akan memainkan peran penting bagi terjadinya prilaku-prilaku yang akan datang ${ }^{12}$

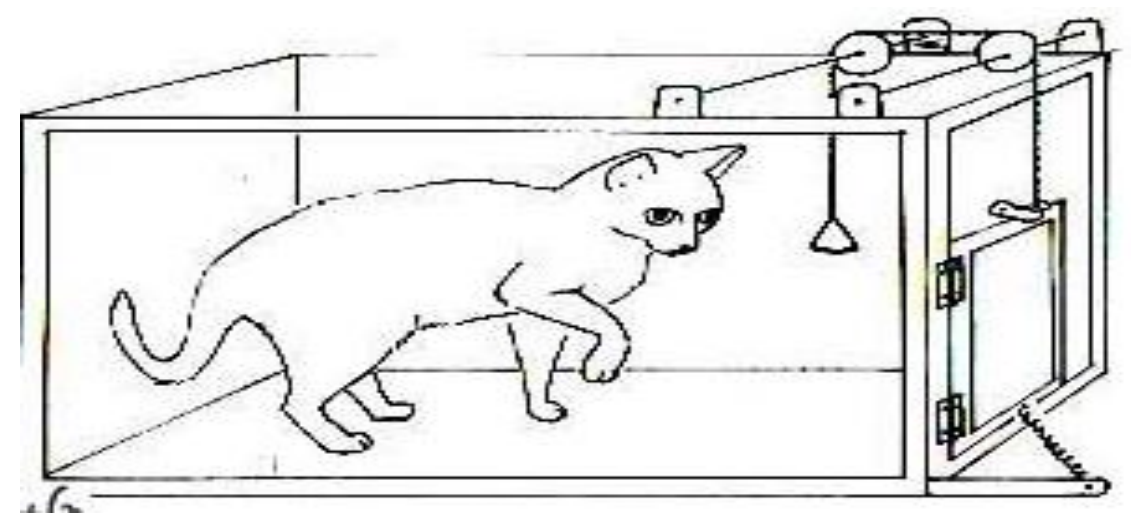

Subjek riset Thorndike termasuk kucing. Untuk melihat bagaimana hewan belajar perilaku yang baru, Thorndike menggunakan ruangan kecil yang ia sebut puzzle box (kotak teka-teki). Seekor kucing lapar ditempatkan berbentuk kotak berjeruji yang dilengkapi dengan peralatan, seperti pengungkit, gerendel, pintu, dan tali yang menghubungkan pengungkit dengan gerendel tersebut. Peralatan ini ditata sedemikian rupa sehingga memungkinkan kucing tersebut memperoleh makanan yang tersedia didepan sangkar tadi dan jika hewan itu melakukan respons yang benar (seperti menarik tali, mendorong tuas, atau mendaki tangga), pintu akan terbuka dan hewan tersebut akan diberi hadiah makanan yang diletakkan tepat di luar kotak.

Koneksionisme merupakan teori yang paling awal dari rumpun behaviorisme. ${ }^{13}$ Teori ini disebut dengan teori koneksionisme atau juga disebut "S -R Bond Theory" dan "S-R Psycology of learning" selain itu, teori ini juga terkenal dengan "Trial and Error Learning"14

Menurut Thorndike, ada beberapa hukum pokok dalam proses belajar manusia, antara lain:

a. Law of Readiness, yaitu kesiapan untuk bertindak itu timbul karena penyesuaian diri dengan sekitarnya yang akan memberikan kepuasan, hubungan antara stimulus dan respon akan mudah terbentuk apabila ada kesiapan pada diri seseorang.

b. Law of Exercise, hubungan antara stimulus dan respon itu akan sangat kuat bila sering dilakukan pelatihan dan pengulangan, dan akan menjadi lemah jika latihan tidak diteruskan.

\footnotetext{
${ }^{12}$ Zalyana, Psikologi Pembelajaran ..., h. 113-114

${ }^{13}$ Suyono dan Harianto, Belajar dan ..., h. 60

${ }^{14}$ Dale H. Schunk, Learning ..., h. 101
} 


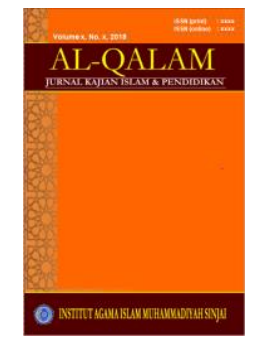

AL-QALAM

Jurnal Kajian Islam \& Pendidikan

Volume 8, No. 2, 2016

ISSN (print) : 1858-4152

ISSN (online) : xxxx-xxxx

Homepage : http://journal.iaimsinjai.ac.id/index.php/al-qalam

c. Law of Effect, yaitu perbuatan yang diikuti dengan dampak atau pengaruh yang memuaskan cenderung ingin diulangi lagi dan yang tidak mendatangkan kepuasan akan dilupakan. ${ }^{15}$

Tentang perubahan tingkah laku akibat kegiatan belajar berwujud konkrit terutama yang dapat diamati, Islam menjelaskan dalam ilmu hadits sesuai dengan pengertiannya; tasydid bil halqi, wal ikraru bil lisan, wal arkanu bil arkan, maksudnya ilmu tanpa amal akan sia-sia belaka, karena tidak cukup hanya dengan kecerdasan akal dan kecerdasan emosional semata akan tetapi juga yang lebih penting adalah bukti nyata.

Firman Allah SWT dalam al-Qur'an :

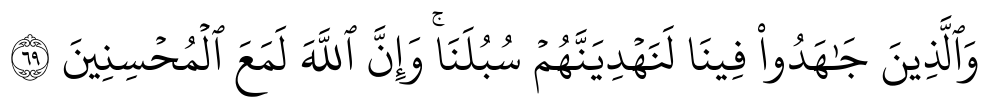

Terjemahan :

Dan orang-orang yang berjihad untuk (mencari keridhaan) Kami, benar-benar akan Kami tunjukkan kepada mereka jalan-jalan Kami. Dan sesungguhnya Allah benar-benar beserta orang-orang yang berbuat baik (Q.S Al-Ankabut : 69)

3. Burrhus Frederic Skinner

Skinnar menoemhaonkan tenri S_R melalui ekcnerimen denoan Skinner Box ${ }^{16}$

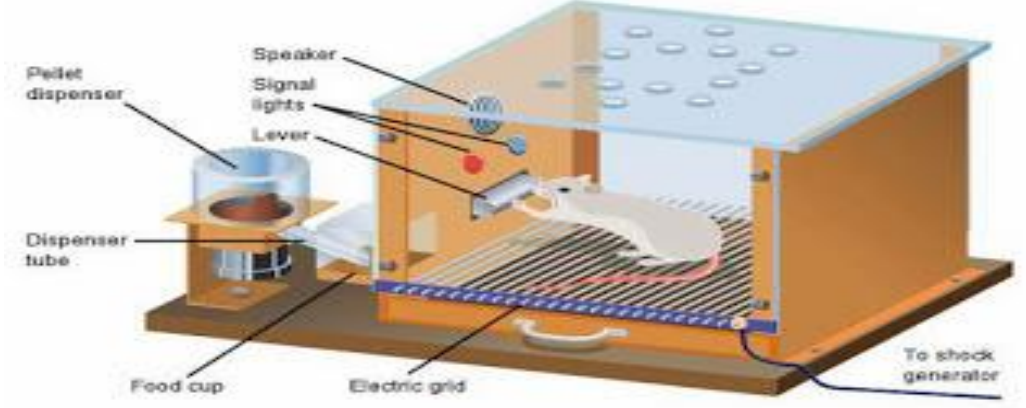

Skinner merupakan seorang tokoh behavioris yang meyakini bahwa perilaku individu dikontrol melalui proses operant conditioning dimana seseorang dapat mengontrol tingkah laku organisme melalui pemberian reinforcement (balikan) yang bijaksana dalam lingkungan yang relatif besar.

Teori belajar behaviorisme ini telah lama dianut oleh para guru dan pendidik, namun dari semua pendukuung teori ini, teori Skinnerlah yang paling besar pengaruhnya terhadap perkembangan teori belajar Behaviorisme. Program-program pembelajaran seperti Teaching Machine, pembelajaran berprogram, modul dan program-program pembelajaran lain yang berpijak pada konsep hubungan stimulusrespons serta mementingkan faktor-faktor penguat merupakan program-program pembelajaran yang menerapkan teori belajar yang dikemukakan oleh skinner. ${ }^{17}$

Menurut skinner berdasarkan percobaanya terhadap tikus unsur terpenting dalam belajar adalah penguatan. Maksudnya adalah penguatan yang terbentuk melalui ikatan stimulus respon akan semakin kuat bila diberi penguatan ( penguatan

\footnotetext{
${ }^{15}$ Suyono dan Harianto, Belajar dan ..., h. 61

${ }^{16}$ Abdullah Idi, Pengembangan Kurikulum, (Jogjakarta ; Ar-Ruzz Media, 2010), h. 83

${ }^{17}$ C. Asri Budiningsih, Belajar..., hlm. 22
} 
positif dan penguatan negatif).Bentuk penguatan positif berupa hadiah, perilaku, atau penghargaan. Sedangkan bentuk penguatan negatif adalah antara lain menunda atau tidak memberi penghargaan, memberikan tugas tambahan, atau menunjukkan perilaku tidak senang.

Skinner tidak sependapat pada asumsi yang dikemukakan Guthrie bahwa hukuman memegang peranan penting dalam proses pelajar. Hal tersebut dikarenakan menurut skinner :

a. Pengaruh hukuman terhadap perubahan tingkah laku sangat bersifat sementara.

b. Dampak psikologis yang buruk mungkin akan terkondisi (menjadi bagian dari jiwa terhukum) bila hukuman berlangsung lama.

c. Hukuman mendorong si terhukum mencari cara lain (meskipun salah dan buruk) agar ia terbebas dari hukuman.

d. Hukuman dapat mendorong si terhukum melakukan hal-hal lain yang kadangkala lebih buruk dari pada kesalahan pertama yang diperbuatnya. ${ }^{18}$

Skinner lebih percaya kepada apa yang disebut sebagai penguat negatif. Penguat negatif tidak sama dengan hukuman. Ketidaksamaannya terletak pada bila hukuman harus diberikan (sebagai stimulus) agar respon yang akan muncul berbeda dengan respon yang sudah ada, sedangkan penguat negatif (sebagai stimulus) harus dikurangi agar respon yang sama menjadi semakin kuat. Misalnya, seseorang siswa perlu dihukum karena melakukan kesalahan. Jika siswa tersebut masih saja melakukan kesalahan, maka hukumannya harus ditambahkan. Tetapi jika sesuatu yang tidak mengenakkan siswa (sehingga ia melakukan kesalahan) dikurangi (bukan malah ditambah) dan pengurangan ini mendorong siswa untuk memperbaiki kesalahnnya, maka inilah yang disebut penganut negatif. Lawan dari penganut negatif adalah penguat positif (positive reinforcement). Keduanya bertujuan untuk memperkuat respon. Namun bedanya adalah bahwa penguat positif itu ditambah, sedangkan penganut negatif adalah dikurangi untuk memperkuat respon. ${ }^{19}$

Menurut Skinner hubungan antara stimulus dan respon yang terjadi melalui interaksi dengan lingkungannya, yang kemudian menimbulkan perubahan tingkah laku, tidaklah sesederhana itu yang dikemukakan oleh tokoh-tokoh sebelumnya. Menurutnya respon yang diterima seseorang tidak sesederhana itu, karena stimulus-stimulus yang diberikan akan saling berinteraksi dan interaksi antar stimulus itu akan memengaruhi respon yang dihasilkan. Respon yang diberikan ini memiliki konsekuensi-konsekuensi. Konsekuensi-konsuekensi inilah yang nantinya memengaruhi menculnya perilaku. Oleh karena itu dalam memahami tingkah laku seseorang secara benar harus memahami hubungan antara stimulus yang satu dengan yang lainnya, serta memahami konsep yang mungkin dimunculkan dan berbagai konsekuensi yang mungkin akan timbul akibat respon tersebut. Skinner juga mengemukakan bahwa dengan menggunakan perubahanperubahan mental sebagai alat untuk menjelaskan tingkah laku hanya akan menambah

\footnotetext{
${ }^{18}$ Ibid, hlm. 25-26

${ }^{19} \mathrm{Ibid}$,
} 


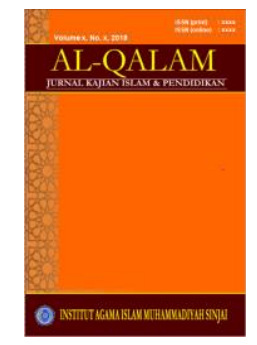

AL-QALAM

Jurnal Kajian Islam \& Pendidiikan

Volume 8, No. 2, 2016

ISSN (print) : 1858-4152

ISSN (online) : xxxx-xxxx

Homepage : http://journal.iaimsinjai.ac.id/index.php/al-qalam

rumitnya masalah. Sebab setiap alat yang digunakan perlu penjelasan lagi, demikian seterusnya.

Mengenai hubungan antar manusia Allah SWT berfirman :

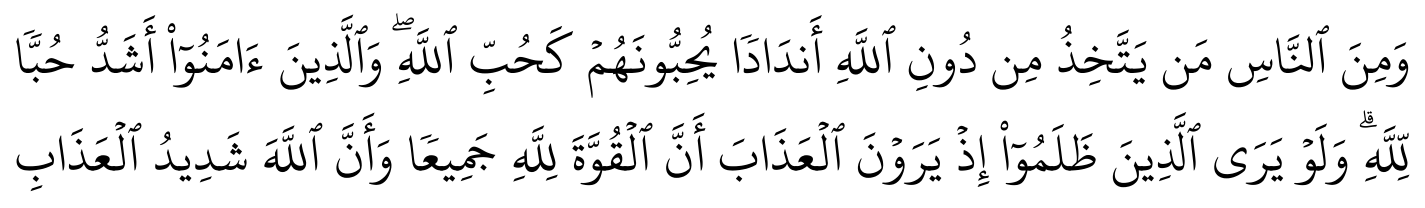

Terjemahan :

Dan diantara manusia ada orang-orang yang menyembah tandingan-tandingan selain Allah; mereka mencintainya sebagaimana mereka mencintai Allah. Adapun orang-orang yang beriman amat sangat cintanya kepada Allah. Dan jika seandainya orang-orang yang berbuat zalim itu mengetahui ketika mereka melihat siksa (pada hari kiamat), bahwa kekuatan itu kepunyaan Allah semuanya, dan bahwa Allah amat berat siksaan-Nya (niscaya mereka menyesal) (Q.S Al-Baqarah: 165)

4. Edwin Ray Guthrie

Edwin Ray Guthrie adalah seorang penemu teori kontinguiti yaitu gabungan stimulus-stimulus yang disertai suatu gerakan, pada waktu timbul kembali cenderung akan diikuti oleh gerakan yang sama. ${ }^{20}$

Teori guthrie ini mengatakan bahwa hubungan stimulus dan respon bersifat sementara, oleh karenanya dalam kegiatan belajar, peserta didik perlu sesering mungkin diberi stimulus agar hubungan stumulus dan respon bersifat lebih kuat dan menetap. Guthrie juga percaya bahwa hukuman (punishment) memegang peranan penting dalam proses belajar. Hukuman yang diberikan pada saat yang tepat akan mampu mengubah tingkah laku seseorang. ${ }^{21}$

Salah asatu eksperimen Guthrie untuk mendukung teori kontiguitas adalah percobaannya terhadap kucing yang dimasukkan ke dalam kotak puzle. Kemudian kucing tersebut berusaha keluar. Kotak dilengkapai dengan alat yang bila disentuh dapat membuka kotak puzle tersebut. Selain itu, kotak tersebut juga dilengkapi dengan alat yang dapat merekam gerakan-gerakan kucing di dalam kotak. Alat tersebut menunjukkan bahwa kucing telah belajar mengulang gerakan-gerakan sama yang diasosiasikan dengan gerakan-gerakan sebelumnya ketika dia dapat keluar dari kotak tersebut. Dari hasil eksperimen tersebut, muncul beberapa prinsip dalam teori kontiguitas, yaitu:

a. Agar terjadi pembiasaan, maka organisme selalu merespon atau melakukan sesuatau

b. Pada saat belajar melibatkan pembiasaan terhadap gerakan-gerakan tertentu, oleh karena itu intruksi yang diberikan harus spesifik.

c. Keterbukaan terhadap berbagai stimulus yang ada merupakan keinginan untuk menghasilkan respon secara umum.

\footnotetext{
${ }^{20}$ Heri Rahyubi, Teori-teori belajar ..., h. 54

${ }^{21}$ Zalyana, Psikologi Pembelajaran ..., h. 125
} 


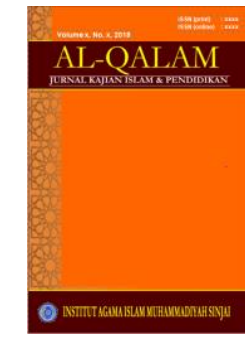

AL-QALAM

Jumal Kajian Islam \& Pendidikan

Volume 8, No. 2, 2016

ISSN (print) : 1858-4152

ISSN (online) : xxxx-xxxx

Homepage : http://journal.iaimsinjai.ac.id/index.php/al-qalam

d. Respon terakhir dalam belajar harus benar ketika itu menjadi sesuatu yang akan diasosiasikan.

e. Asosiasi akan menjadi lebih kuat karena ada pengulangan. ${ }^{22}$

Saran utama dari teori ini adalah guru harus dapat mengasosiasi stimulus respon secara tepat. Peserta didik harus dibimbing melakukan apa yang harus dipelajari. Dalam mengelola kelas guru tidak boleh memberikan tugas yang mungkin diabaikan oleh anak. Mengenai kewajiban siswa untuk dapat melaksanakan tugas yang diberikan oleh guru Islam mengajarkan kepada kita :

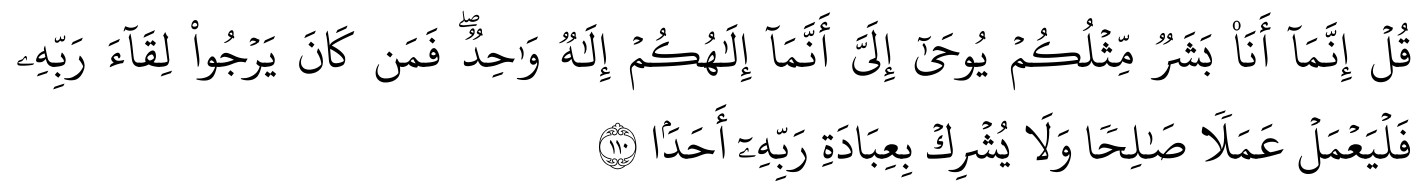

Terjemahan :

Katakanlah: Sesungguhnya aku ini manusia biasa seperti kamu, yang diwahyukan kepadaku: "Bahwa sesungguhnya Tuhan kamu itu adalah Tuhan yang Esa". Barangsiapa mengharap perjumpaan dengan Tuhannya, maka hendaklah ia mengerjakan amal yang saleh dan janganlah ia mempersekutukan seorangpun dalam beribadat kepada Tuhannya" (Q.S Al-khaf : 110)

Seorang manusia seperti kamu, yang telah menerima wahyu, bahwa sesungguhnya Tuhan kamu adalah Tuhan yang Maha Esa." Maka barang siapa mengaharap pertemuan dengan Tuhannya maka hendaklah dia mengerjakan kebajikan dan janganlah dia mempersekutukan dengan sesuatu pun dalam beribadah kepada Tuhannya.

5. Jhon Broadus Waston

John watson adalah penggagas utama aliran behaviorisme di Amerika Serikat $^{23}$. Teori Watson disebut teori classical conditioning yang dipelopori oleh Pavlov menurut teori ini, belajar adalah proses perubahan yang terjadi karena adanya syarat-syarat (conditions) yang kemudian menimbulkan reaksi (respon). Penganut teori ini mengatakan bahwa segala tingkah laku manusia adalah hasil conditioning, yakni hasil dari latihan-latihan atau kebiasaan-kebiasaan bereaksi terhadap syarat-syarat atau perangsang-perangsang tertentu yang di alaminya didalam kehidupannya. ${ }^{24}$

Menurut teori ini, dalam belajar yang penting adalah input yang berupa stimulus dan output yang berupa respon. Stimulus adalah apa saja yang diberikan oleh guru kepada siswa, sedangkan respon adalah reaksi atau tanggapan siswa terhadap stimulus yang diberikan oleh guru tersebut. Proses yang terjadi antara stimulus dan respon tidak penting untuk diperhatikan karena tidak dapat diamati dan tidak dapat diukur. Yang dapat diamati adalah stimulus dan respon yang diekspresikan para murid. Oleh karena itu apa yang diberikan oleh guru (stimulus) dan apa yang dieksperikan oleh siswa (respon) harus dapat diamati dan diukur. Berikut skema belajar menurut John B. Watson ${ }^{25}$

\footnotetext{
${ }^{22}$ Ibid, h. 123-124

${ }^{23}$ Heri Rahyubi, Teori-teori belajar ..., h. 15

${ }^{24}$ Muhammad Tabroni dan Arif Mustafa, Belajar ..., h. 72

${ }^{25}$ Heri Rahyubi, Teori-teori belajar ..., h. 19
} 


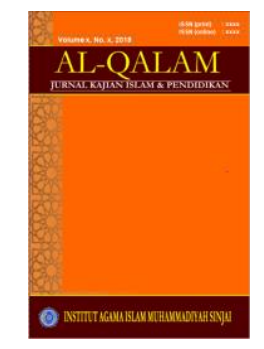

AL-QALAM

Jurnal Kajian Islam \& Pendidilkan

Volume 8, No. 2, 2016

ISSN (print) : 1858-4152

ISSN (online) : xxxx-xxxx

Homepage : http://journal.iaimsinjai.ac.id/index.php/al-qalam

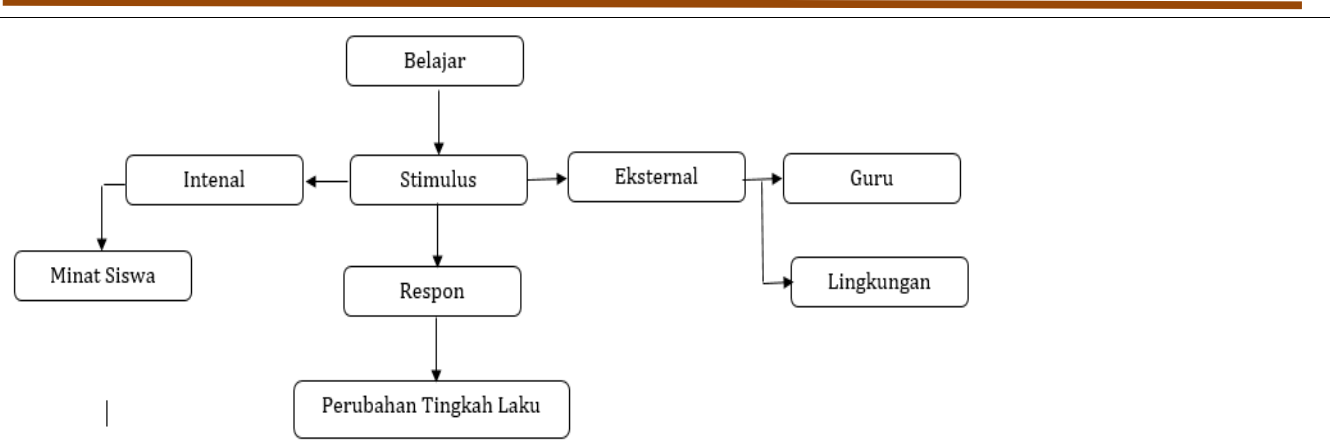

Pemahaman keagamaan yang dimiliki oleh seseorang klasifikasinya adalah sebagai berikut : muqollid, muttabi dan mujtahid. Hal itu tentu saja dapat diamati dan diukur, contohnya jika banyak orang melaksanakan sholat tarawih dengan maksud mendapat jatah sembako itu berarti Islam abangan/munafiqin, kemudian seorang muslim yang melaksanakan rukun Islam dan rukun Iman dengan sempurna berdasarkan tuntunan al-Qur'an dan Sunnah rosul yang diajarkan oleh ustdz termasuk golongan mukminin kemudian bila kita mengenal lewat karya monumental kitab-kitab klasik dan pemikir kontemporer seperti Ibnu Maskawaih, Ibnu sina, Imam Syafi'i, Imam maliki dan lain sebagainya jelas mereka dapat kita ukur sebagai ahli surge kelompok Mujtahid.

Firman Allah SWT dalam al-Qur'an :

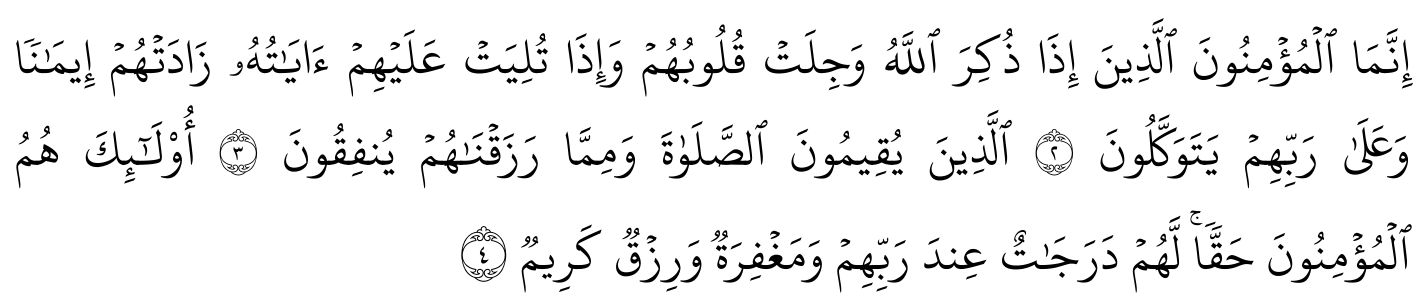

Terjemahan:

Sesungguhnya orang-orang yang beriman ialah mereka yang bila disebut nama Allah gemetarlah hati mereka, dan apabila dibacakan ayat-ayat-Nya bertambahlah iman mereka (karenanya), dan hanya kepada Tuhanlah mereka bertawakkal. (yaitu) orang-orang yang mendirikan shalat dan yang menafkahkan sebagian dari rezeki yang Kami berikan kepada mereka. Itulah orang-orang yang beriman dengan sebenar-benarnya. Mereka akan memperoleh beberapa derajat ketinggian di sisi Tuhannya dan ampunan serta rezeki (nikmat) yang mulia (QS. Al-Anfal Ayat 2-4)

6. Clark Hull

Chark Hull adalah seorang behavioris yang amat terpengaruh oleh teori evolusi charles darwin, bagi Hull semua fungsi tingkah laku itu berfungsi menjaga agar oranisasi tetap bertahan hidup. Konsep sentral dalam teorinya berkisar pada kebutuhan biologis dan pemuas kebutuhan, hal yang penting bagi kelangsungan hidup ${ }^{26}$

Prinsip-prinsi utama teori Hull $:^{27}$

\footnotetext{
${ }^{26}$ Suryono dan Haryanto, Belajar ..., h. 63

${ }^{27}$ Heri Rahyubi, Teori-teori belajar ..., h. 47
} 


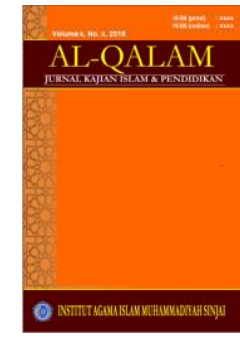

AL-QALAM

Jurnal Kajian Islam \& Pendidikan

Volume 8, No. 2, 2016

ISSN (print) : 1858-4152

ISSN (online) : xxxx-xxxx

Homepage : http://journal.iaimsinjai.ac.id/index.php/al-qalam

a. Reinfocement adalah faktor penting dalam belajar yang harus ada

b. Dalam Pemenuhan hubungan S-R yang perlu dikaji adalah peranan dari intervening varieble (Variabel penghalang)

c. Proses belajar baru terjadi setelah keseimbagan biologis terjadi.

Secara ringkas teori behaviorisme yang dikemukakan oleh para ahli di atas dapat disempulkan bahwa:

a. Belajar adalah perubahan tingkah laku

b. Tingkah laku tersebut harus dapat diamati

c. Mengikuti pentingnya masukan atau input yang berupa stimulus dan keluaran atau output yang berupa respon.

d. Fungsi mind atau fikiran adalah untuk menciplak struktur pengetahuan yang sudah ada melalui proses berfikir yang dapat dianalisis dan dipilah.

e. Pembiasaan dan latihan menjadi esensial dalam belajar.

f. Apa yang terjadi antara stimulus dan respon dianggap tidak penting diperhatikan karena tidak dapat diamati.

g. Yang dapat diamati hanyalah stimulus respon.

h. Kegagalan atau ketidakmampuan dalam penambahan pengetahauan dikatagorikan sebagai kegagalan yang perlu dihukum

i. Aplikasi teori ini menuntut siswa untuk mengungkapkan kembali pengetahuan yang sudah dipelajari dalam bentuk laporan, kuis atau tes. Penyajian materi pelajaran mengikuti urutan dari bagian-bagian keseluruhan. Pembelajaran dan evalusi menekan pada hasil, dan evaluasi menuntut jawaban yang benar. Jawaban yang benar menunjukkan bahwa siswa telah menyelesaikan belajaranya. ${ }^{28}$

j. Proses belajar sangat bergantung kepada faktor yang berada di luar dirinya, sehingga ia memerlukan stimulus dari pengajarnya.

k. Hasil belajar banyak ditentukan oleh proses peniruan, pengulanagn dan pengutan (reinforcement).

1. Belajar harus melalui tahap-tahap tertentu, sedikit demi sedikit, yang mudah mendahului yang lebih sulit. ${ }^{29}$

Clark Hull juga menggunakan variable hubungan antara stimulus dan respon untuk menjelaskan pengertian belajar. Namun sangat terpengaruh oleh teori evolusi Charles Darwin. Bagi Hull, seperti hal nya teori evolusi, semua fungsi tingkah laku bermanfaat terutama untuk menjaga agar organisme tetap bertahan hidup. Oleh sebab itu Hull mengatakan kebutuhan biologis (drive) dan pemuasan kebutuhan biologis (drive reduction) adalah penting dan menempati posisi sentral dalam seluruh kegiatan manusia, sehingga stimulus (stimulus dorongan) dalam belajar pun hampir selalu dikaitkan dengan kebutuhan biologis, walaupun respon yang akan muncul mungkin akan dapat berwujud macam-macam. Penguatan tingkah laku juga masuk dalam teori ini, tetapi juga dikaitkan dengan kondisi biologis.

\footnotetext{
${ }^{28}$ Zalyana, Psikologi Pembelajaran ..., h. 126

${ }^{29}$ Iskndarwasid dan Hadang Sunendar, Strategi Pembelajaran Bahasa, (Bandung: PT Remaja Rosdakarya, 2011), h.47
} 


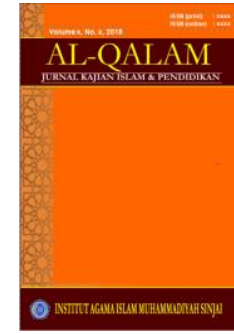

AL-QALAM

Jurnal Kajian Islam \& Pendidikan

Volume 8, No. 2, 2016

ISSN (print) : 1858-4152

ISSN (online) : xxxx-xxxx

Homepage : http://journal.iaimsinjai.ac.id/index.php/al-qalam

Dalam pandangan Islam, mengenai struggle for life (bertahan untuk hidup) atau dalam pandangan ekonomi ada kebutuhan primer, sekunder, tertier dan mewah, diarahkan untuk Ibadah tercantum dalam Q.S. Al-An'am ayat 162-163 :

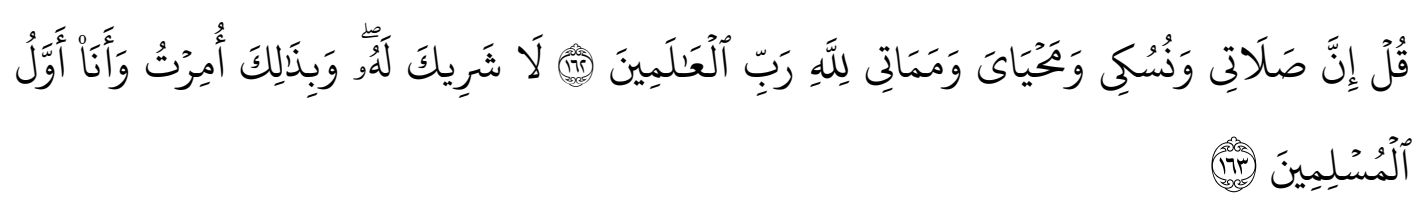

Terjemahan :

Katakanlah: sesungguhnya sembahyangku, ibadatku, hidupku dan matiku hanyalah untuk Allah, Tuhan semesta alamTiada sekutu bagi-Nya; dan demikian itulah yang diperintahkan kepadaku dan aku adalah orang yang pertama-tama menyerahkan diri (kepada Allah)" (Q.S Al-An'am Ayat 162-163)

\section{Aplikasi Teori Belajar Behavioristik dalam Pembelajaran}

Secara umum langkah-langkah pembelajaran yang berpijak pada teori behavioristik dapat digunakan dalam merancang pembelajaran, langkah-langkah pembelajara tersebut antara lain : $:^{30}$

1. Menentukan tujuan-tujuan pembelajaran

2. Menganalisis lingkungan kelas yang ada saat ini termasuk mengidentifikasi pengetahuan awal siswa

3. Menentukan materi pembelajaran

4. Memecah materi pembelajaran menjadi bagian kecil-kecil, meliputi pokok bahasan, sub pokok bahasan, topik dsb

5. Menyajikan materi pembelajaran

6. Memberikan stimulus, dapat berupa, pertanyaan baik lisan maupu tertulis, tes atau kuis, latihan atau tugas-tugas

7. Mengamati dan mengkaji respon yang diberikan siswa

8. Memberikan penguatan atau reinforcement (mungkin penguatan positif ataupun penguatan negatif), ataupun hukuman

9. Memberikan stimulus baru

10. Memberikan penguatan lanjutan atau hukuman

11. Evaluasi belajar

Dalam teori ini Behaviorisme, segala tingkah laku manusia menjadi suatu prilaku berbahsa yang menjadi manifestasi stimulus dan respon yang dilakukan terus-menerus menjadi suatu kebiasaan. Berdasarkan teori ini, pembelajaran bahasa dilakukan dengan mendahulukan pengenalan keterampilan mendengar dan berbicara daripada keterampilan lainnya, pemberian latihan-latihan dan penggunaan bahasa secara aktif dan terus menerus, penciptaan lingkungan berbahasa yang kondusif, penggunaan media pembelajaran yang memungkinkan siswa mendengar dan berinteraksi dengan penutur asli, pembiasaan motivasi sehingga berbahsa asing menjadi sebuah prilaku kebiasaan. ${ }^{31}$

\footnotetext{
${ }^{30}$ Yatim Riyanto, Paradigma Baru Pembelajaran,(Jakarta : Pranada Media Group, 2009), h. 30

${ }^{31}$ Aziz Fachrurrazi dan Erta Mahyudin, Pembelajaran Bahasa asing,(jakarta:Bania Publising, 2010),h...38
} 


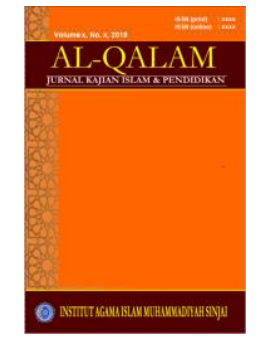

AL-QALAM

Jumal Kajian Islam \& Pendidikan

Volume 8, No. 2, 2016

ISSN (print) : 1858-4152

ISSN (online) : xxxx-xxxx

Homepage : http://journal.iaimsinjai.ac.id/index.php/al-qalam

Para pakar Psikologi belajar bahasa penganut faham Behaviorisme berpendapat bahwa belajar bahasa berlangsung dalam lima tahap, yaitu:

1. Trial and error

2. Mengingat-ingat

3. Menirukan

4. Mengasosiasikan

5. Menganalogikan

Dari kelima langkah tersebut dapat disimpulkan bahwa berbahasa pada dasarnya merupakan proses pembentukan kebiasaan. ${ }^{32}$

Ada beberapa kegiatan pembelajaran bahasa Arab yang dapat dikembangkan berdasarkan teori ini, diantara yang penting adalah: ${ }^{33}$

1. Pengenalan ketrampilan mendengar dan berbicara sebagai awal dalam pembelajaran sebelum ketrampilan membaca dan menulis.

2. Latihan dan penggunaan bahasa secara aaktif dan terus menerus agar pembelajar memiliki ketrampilan berbahasa dan berbentuk kebiasaan menggunakan bahasa.

3. Penciptaan lingkungan berbahsa yang kondusif agar mendukung proses pembiasaan berbahasa secara efektif.

4. Penggunaan media pembelajaran yang memungkinkan pembelajar mendebgar dan berinteraksi dengan penutur asli.

5. Memotivasi guru bahasa untuk tampil berbahsa secara baik dan benar, sehingga dapat menjadi teladan yang baik bagi para siswanya dalam berbahasa

\section{Kelebihan dan Kekurangan Pemebelajaran Behavioristik}

Dalam teknik pembelajaran yang merujuk ke teori behaviouristik terdapat beberapa kelebihan di antaranya $:^{34}$

1. Membiasakan guru untuk bersikap jeli dan peka pada situasi dan kondisi belajar.

2. Guru tidak banyak memberikan ceramah sehingga murid dibiasakan belajar mandiri. Jika menemukan kesulitan, baru ditanyakan kepada guru yang bersangkutan.

3. Mampu membentuk suatu prilaku yang diinginkan mendapatkan penguatan positif dan prilaku yang sesuia mendapat penghargaan negatif yang didasari dengan prilaku yang tampak

4. Dengan melalui pengulangan dan pelatihan yang berkesinambungan, dapat mengoptimalkan bakat dan kecerdasan siswa yang sudah terbentuk sebelumnya. Jika anak sudah mahir dalam bidang tertentu, akan lebih dikuatkan lagi dengan pembiasaan atau pengulangan yang berkesinambungan tersebut dan lebih optimal

5. Bahan pelajaran disusun secara hirarkis dari yang sederhana sampai kompleks dengan tujuan pembelajaran dibagi dalam bagian-bagian kecil yang ditandai dengan pencapaian suatu keterampilan tertentu mampu menghasilkan suatu perilaku konsisten terhadap bidang tertentu

6. Dapat mengganti stimulus yang satu dengan srimulus yang lainnya dan seterusnya sampai respon yang diinginkan muncul

\footnotetext{
${ }^{32}$ Zalyana, Psikologi Pembelajaran ... hlm 127-128

${ }^{33}$ Aziz Fachrurrazi dan Erta Mahyudin, Pembelajaran ..., hlm. 37

${ }^{34}$ Muhammad Thobrani dan Arif Mustafa, Belajar ..., hlm. 85-86
} 


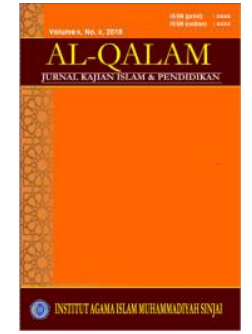

AL-QALAM

Jurnal Kajian Islam \& Pendidikan

Volume 8, No. 2, 2016

ISSN (print) : 1858-4152

ISSN (online) : xxxx-xxxx

Homepage : http://journal.iaimsinjai.ac.id/index.php/al-qalam

7. Metode behavioristik ini sangat cocok untuk memperoleh kemampuan yang menbutuhkan praktek dan pembiasaan yang mengandung unsur-unsur seperti: kecepatan, spontanitas, kelenturan, refleksi, daya tahan, dan sebagainya.

8. Teori ini cocok diterapkan untuk melatih anak-anak yang masih membutuhkan dominansi peran orang dewasa, suka mengulangi dan harus dibiasakan, suka meniru dan senang dengan bentuk-bentuk penghargaan langsung seperti diberi permen atau pujian.

Kekurangan dari teori belajar behaviorisme adalah :

1. Memandang belajar sebagai kegiatan yang dialami langsung, padahal belajar adalah kegiatan yang ada dalam sistem syaraf manusia yang tidak terlihat kecuali melalu gejalanya.

2. Proses belajar dipandang bersifat otomatis-mekanis sehingga terkesan seperti mesin atau robot, padahal manusia mempunyai kemampuan self control yang bersifat kognitif, sehingga, dengan kemampuan ini, manusia mampu menolak kebiasaan yang tidak sesuai dengan dirinya.

3. Proses belajar manusia yang dianalogikan dengan hewan sangat sulit diterima, mengingat ada perbedaan yang cukup mencolok antara hewan dan manusia ${ }^{35}$

\section{E. Pandangan Islam Tentang Teori Behaviorisme}

Menurut Skinner, keyakinan manusia terhadap suatu agama dan upacara ritual untuk mengagungkan Tuhan merupakan tingkah laku tahayul dari burung dara yang kelaparan yang terus menerus mengulangi gerakan khusus berdasarkan sistem penguatan (reinforcement). Uraian ini menunjukkan bahwa paham Skinner anti terhadap agama, kedua, dinamika struktur kepribadian manusia disamakan dengan dinamika hewan. Padahal tingkah laku hewan itu sangat jauh berbeda dengan tingkah laku manusia, baik dilihat dari sisi asumsi maupun makna tingkah laku yang diperbuat. Ketiga, teori strukturnya diasumsikan dari konsep manusia yang netral, tidak memiliki potensi bawaan apapun. Keempat, manusia diibaratkan robot yang selalu diprogram secara deterministik. Teori inilah yang mendapat kritikan dari Psiko-humanistik bahwa "teori Psiko-behavioristik memandang manusia sebagai suatu mesin, yaitu sistem kompleks yang bertingkah laku menurut cara yang sesuai dengan hukum. ${ }^{36}$

Behaviourisme memusatkan perhatiannya pada wilayah objektivitas. Behaviourisme memandang Psikoanalisa sebagai teori yang sangat spekulatif dan tidak ilmiah. Penjelajahan terhadap wilayah unconsciousness (ketidaksadaran) dengan menggunakan metode hipnotis, intropeksi, retropeksi, dan analisis mimpi merupakan metode yang menggambarkan spekulatif-subjektif. Behaviourisme yakin dan percaya bahwa seluruh tingkah laku manusia dapat dipahami (understanding), dirumuskan (formulasi), dan diprediksi (prediction), berdasarkan pandangan objektif. Maka rumusan tingkah laku bagi behaviourisme merupakan hubungan stimulus-respond-bond. ${ }^{37}$

\footnotetext{
${ }^{35}$ Zalyana, Psikologi Pembelajaran..., hlm 127-128

${ }^{36}$ Abdul Mujib dan Jusuf Mudzakir, Nuansa-nuansa Psikologi Islam, (Jakarta: PT Raja Grafindo Persada, 2002) h.73-74

${ }^{37}$ Baharuddin, Paradigma Psikologi Islami, (Yogyakarta: Pustaka Pelajar, 2004) h. 384
} 
Behaviourisme disebut islami karena ia mengajarkan besarnya pengaruh lingkungan terhadap manusia sebagaimana ungkapan sebuah hadits (yang artinya: "Manusia dilahirkan dalam keadaan suci, maka kedua orang tuanyalah yang menjadikannya Yahudi, Nasroni atau Majusi." H.R.Bukhari)

Sebagai contoh, karena sangat terpesona oleh teori refleks terkondisi dari kaum behaviourisme, maka Faiz Al-Hajj, dalam disertasinya mencoba mencari-cari beberapa pemikiran Al-Ghazali yang sesuai dengan teori refleks terkondisi itu. ${ }^{38}$ Mengacu pada pandangan Al Ghazali tentang al-Qur'an mengenai manusia, Hanna Djumhana Bastaman menandai wawasan islam mengenai manusia sebagai berikut:

1. Al-Qur'an memberi penghargaan yang cukup tinggi terhadap martabat umat manusia dengan julukan kehormatan yang diberikan kepada manusia sebagai "khalifah di bumi".

2. Fitrah manusia adalah suci dan beriman.

3. Al-Qur'an menyatakan adanya ruh pada manusia di samping raga dan jiwanya. Ruh ini sudah ada sebelum manusia dilahirkan, selama ia masih hidup, dan setelah berpulang.

Ketiga hal ini yang membedakan antara wawasan Islami dengan wawasan filsafat dan teori psikologi yang ada. Landasan ini menunjukkan bahwa kajian Islami hendaknya meliputi dimensi ruhani (spiritual-imani) selain dimensi ragawi (fisik-biologis), dimensi kejiwaan (psikologi edukasi) dan dimensi lingkungan (sosio-kultural). Demikian pula dengan akal (al-aql), hati (al-qalb), dan an-nafs yang keseluruhannya menjadi bagian tak terpisahkan dalam pengkajian perilaku manusia dalam psikologi Islami.

Aliran Behaviourisme mempelajari terbentuknya perilaku manusia atas dasar konsep stimulus respons yang berarti perilaku manusia sangat terkondisi oleh lingkungan. Lingkungan yang buruk akan menghasilkan manusia yang buruk, sebaliknya lingkungan yang baik menghasilkan manusia yang baik. Selain itu aliran behaviourisme memandang bahwa perilaku manusia terbentuk karena adanya pengaruh dari reinforcement. Dalam hal ini tidak diperbincangkan adanya makna perilaku baik dan buruk, kecuali hasil dari reinforcement sebagai penguat positif atau negatif. Konsep benar dan salah tidak diperhitungkan dalam kajian tentang perilaku manusia.

Perilaku manusia mengikuti hukum sebab-akibat, di mana sebab-sebab itu sendiri dapat dikontrol dan diciptakan. Para ahli aliran behaviouristik berhasil menemukan kaidah-kaidah belajar yang melandasi perubahan perilaku. Hal ini dapat dijadikan acuan dalam kegiatan pendidikan, psikoterapi, dan lain-lain. Kaidah dan hukum belajar ini dapat dianggap sebagai keunggulan dari aliran behavioristik dalam menelaah konsep manusia dikaitkan dengan salah satu fenomena sunnatulah, yaitu bahwa manusia manusia dapat mengubah nasib dirinya. Petunjuk Tuhan bagi mereka yang ingin mengubah nasib dirinya tentunya dapat menggunakan metode dan teknik belajar dengan memanfaatkan temuan-temuan aliran behavioristik. ${ }^{39}$

\footnotetext{
${ }^{38}$ Fuad Nashori, Agenda Psikologi Islami, (Yogyakarta: Pustaka Pelajar, 2002), h.36

${ }^{39}$ Rifaat Syauqi Nawawi, Metodologi Psikologi Islami, (Yogyakarta: Pustaka Pelajar, 2000), hlm.61-62
} 


\section{KESIMPULAN}

Behaviorisme adalah teori perkembangan perilaku, yang dapat diukur, diamati dan dihasilkan oleh respons pelajar terhadap rangsangan. Tanggapan terhadap rangsangan dapat diperkuat dengan umpan balik positif atau negatif terhadap perilaku kondisi yang diinginkan. Terdapat beberapa tokoh yang mengemukakan teori behaviorisme, diantaranya : Thorndike, Watson, Clark Hull, Edwin Guthrie, dan Skinner. Adapun ciri-ciri dari teori behaviorisme yaitu adalah mengutamakan unsur-unsur dan bagian kecil, bersifat mekanistis, menekankan peranan lingkungan, mementingkan pembentukan reaksi atau respon, menekankan pentingnya latihan, mementingkan mekanisme hasil belajar,mementingkan peranan kemampuan dan hasil belajar yang diperoleh adalah munculnya perilaku yang diinginkan.

Aplikasi teori behavioristik dalam kegiatan pembelajaran tergantung dari beberapa hal seperti: tujuan pembelajaran, sifat materi pelajaran, karakteristik pebelajar, media dan fasilitas pembelajaran yang tersedia. Pembelajaran yang dirancang dan berpijak pada teori behavioristik memandang bahwa pengetahuan adalah obyektif, pasti, tetap, tidak berubah. Implikasi yang digunakan dalam teori ini yaitu bahwa pengetahuan telah terstruktur rapi dan teratur, maka pembelajar atau orang yang belajar harus dihadapkan pada aturan-aturan yang jelas dan ditetapkan terlebih dulu secara ketat yang bertujuan menuntut pembelajar untuk mengungkapkan kembali pengetahuan yang sudah dipelajari dalam bentuk laporan, kuis, atau tes.

Aliran Behaviourisme mempelajari terbentuknya perilaku manusia atas dasar konsep stimulus respons yang berarti perilaku manusia sangat terkondisi oleh lingkungan. Lingkungan yang buruk akan menghasilkan manusia yang buruk, sebaliknya lingkungan yang baik menghasilkan manusia yang baik. Perilaku manusia mengikuti hukum sebabakibat, di mana sebab-sebab itu sendiri dapat dikontrol dan diciptakan. Para ahli aliran behaviouristik berhasil menemukan kaidah-kaidah belajar yang melandasi perubahan perilaku. Hal ini dapat dijadikan acuan dalam kegiatan pendidikan, psikoterapi Kaidah dan hukum belajar ini dapat dianggap sebagai keunggulan dari aliran behavioristik dalam menelaah konsep manusia dikaitkan dengan salah satu fenomena sunnatulah, yaitu bahwa manusia manusia dapat mengubah nasib dirinya.

\section{DAFTAR PUSTAKA}

Budiningsih, C. Asri, Belajar dan Pembelajaran, Jakarta: PT. Rineka Cipta, 2005

Baharuddin, Paradigma Psikologi Islami, Yogyakarta: Pustaka Pelajar, 2004

Fachrurrazi, Aziz dan Erta Mahyudin, Pembelajaran Bahasa asing, Jakarta:Bania Publising, 2010

Gage, N.L., \& Berliner, D. Educational Psychology. 1979

Idi, Abdullah. Pengembangan Kurikulum, Jogjakarta ; Ar-Ruzz Media, 2010 


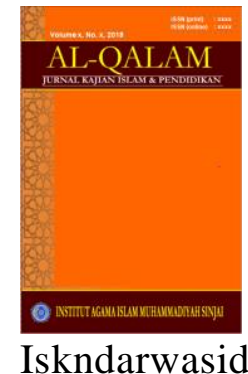

AL-QALAM

Jurnal Kajian Islam \& Pendidikan

Volume 8, No. 2, 2016

ISSN (print) : 1858-4152

ISSN (online) : xxxx-xxxx

Homepage : http://journal.iaimsinjai.ac.id/index.php/al-qalam

Iskndarwasid dan Hadang Sunendar, Strategi Pembelajaran Bahasa, Bandung: PT Remaja Rosdakarya, 2011

Mujib , Abdul dan Jusuf Mudzakir, Nuansa-nuansa Psikologi Islam, Jakarta: PT Raja Grafindo Persada, 2002

Nashori,Fuad, Agenda Psikologi Islami, Yogyakarta: Pustaka Pelajar, 2002

Nawawi, Rifaat Syauqi, Metodologi Psikologi Islami, Yogyakarta: Pustaka Pelajar, 2000

Rahyubi, Heri, Teori-teori belajar dan aplikasi pembelajaran motorik, Bandung : Referens Publishing dan Nusamedia, 2013

Schunk, Dale H Learning Teories, Yogyakarta : Pustaka Pelajar, 2012

Smith, Mark K. dkk, Teori Pembelajaran dan Pengajaran, Jogjakarta: Mirza Media Pustaka,2010

Sukarjo M. dan Ukim Komarudin, Landasan Pendidikan, Jakarta: PT. Raja Grafindo Persada, 2012

Suyono dan Harianto, Belajar dan Pembelajaran, Bandung : Belajar dan Pembelajaran, 2012

Tabroni, Muhammad dan Arif Mustafa, Belajar dan Pembelajaran, Jogjakarta : Ar-Ruzz Madia, 2011

Zalyana, Psikologi Pembelajaran Bahasa Arab, Pekanbaru: Almujtahadah Press, 2010 